\title{
観測資料および推算資料を用いた 伊勢湾口における波候の解析 ANALYSIS OF WAVE CLIMATE CONDITIONS AT THE ENTRANCE OF ISE BAY
USING MEASUREMENT DATA AND HINDCAST DATA
}

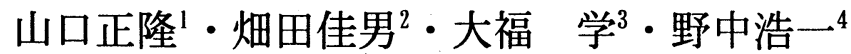 \\ Masataka YAMAGUCHI,Yoshio HATADA, Manabu OHFUKU and Hirokazu NONAKA \\ '正会員 工博 愛媛大学教授 工学部環境建設工学科（T790-8577 松山市文京町3番） \\ ${ }^{2}$ 正会員 博士（工学） 愛媛大学助手 工学部環境建設工学科 \\ 愛媛大学技術専門職員 工学部環境建設工学科 \\ ${ }^{4}$ 正会員 博士 (工学) 愛媛大学科研研究支援者 工学部環境建設工学科
}

\begin{abstract}
This paper deals with the estimation of wave climate conditions at the entrance of Ise Bay which have not been extensively investigated. First, based on the statistical analyses of wind and wave data measured over several years at 3 buoy stations, climatic conditions of winds and waves at the entrance area are discussed. Next, a long term wave hindcast system on a nested grid with high space resolution of $1 \mathrm{~km}$ is applied location by location under 20-year ECMWF and 51-year NCEP/NCAR surface wind data conditions. Findings are that the system reproduces well the wave climate condition evaluated from the measurement data at each of the 3 stations and that any wave height climate parameter does not indicate an increasing or decreasing trends with statistical significance over the recent 41 -year period.
\end{abstract}

Key Words: wind and wave climates, Ise Bay, measurement and hindcast data, trend analysis

\section{1. 緒 言}

我が国の沿岸部には，海岸の保全や災害防止あるい は沿岸構造物の耐波設計などのための基礎資料を収集す ることを目的として，（旧)運輸省・建設省(現国土交通 省), 気象庁, 水産庁, 県, 電力会社などによって多く の波高計が設置されており, 結果として沿岸波浪に対す る高密度で充実した観測体制が構成されているけれども, 依然として波浪観測地点の空白域が存在する。その1つ が遠州灘から熊野灘に至る沿岸域である。

しかし最近, 当該沿岸域の中央部にあたる伊勢湾口 では, (旧)建設省中部地方建設局により, 複数地点にお ける風および波浪の長期定点ブイ観測" が実施されてき た。これらの観測資料は, 重複する期間内に同一海域の 沖合地点と岸側地点で得られていることから, 近接する 沿岸地点における風候および波候の解析のみならず，波 浪の長期推算システムの精度の検証のためにきわめて有 用である。

そこで本研究では，伊勢湾口内外に位置するA，B，C の3ブイ地点における数年間の風および波浪観測資料の
解析に基づいて風候および波候の特性を調べたのち，表 面風資料を入力条件とした, 1 点浅海モデルの適用に基 づく波浪の長期推算システム ${ }^{2)}$ ，3にによって, 観測資料 より求めた波候の特性を再現しうるか否かを検討する。 また, 波浪の長期推算資料を用いて3ブイ地点における 過去 20 年間の波候やB地点における過去 51 年間あるいは 41 年間の波高の傾向変動の有無を考察する。

\section{2. 観測資料に基づく風候および波候の解析}

\section{（1）風および波浪観則資料}

図-1は伊勢湾口周辺に設置された3基のブイの位置と 水深を示す。 $\mathrm{A}, \mathrm{B}, \mathrm{C}$ 地点はそれぞれ水深 $92 \mathrm{~m}, 40 \mathrm{~m}, 35 \mathrm{~m}$ の位置にある。A，B地点およびB，C地点の間の距離はそ れぞれ $21 \mathrm{~km}$ おび11 kmである。各ブイ地点における風 （高度4.5m）および波浪の観測資料は2時間ごとに取得 されている。観測資料の期間はA地点で1996年4月〜1998 年 12 月の 2 年 9 ケ月, B地点で 1994 年 4 月〜 1998年 12 月の 4 年 9 ケ月, C地点で 1997 年4月〜 1998年12月の1年9ヶ月で ある。因みに, 波浪資料の測得率はB地点で 0.81 と高く, $A$, C地点で $0.65,0.62$ とやや低い。 


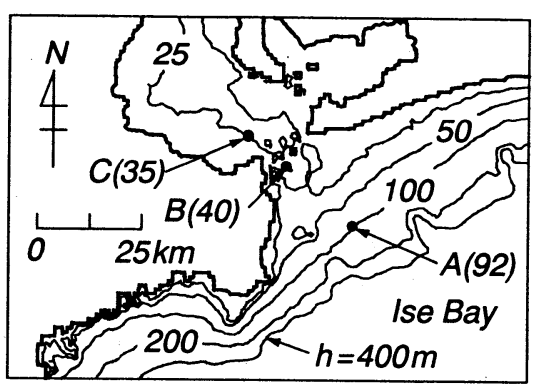

図-1 伊勢湾口周辺におけるブイの位置

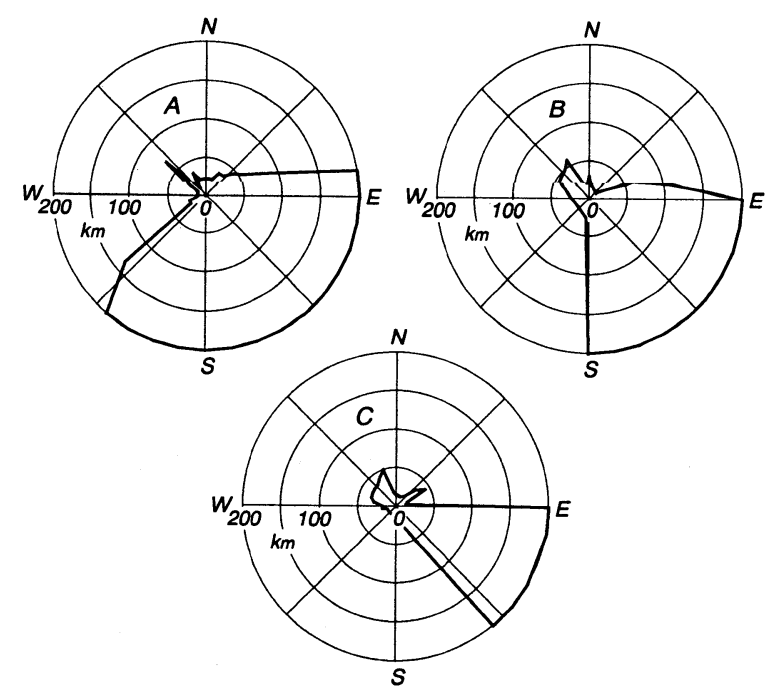

図-2 3ブイ地点における方向別対岸距離
図-2は上限値を $200 \mathrm{~km}$ して描いた 3 ブイ地点における $10^{\circ}$ ごとの方向別対岸距離を表す。 $200 \mathrm{~km}$ をとる方向の 対岸距離は実際には $1000 \mathrm{~km}$ をはるかに越える。A地点はE 〜SWの方向を外海に開いており, 伊勢湾奥部に相当する NWの方向にも70km程度の対岸距離をもつ。B，C地点では, 対岸距離分布は比較的類似するが, 外海から到達する波 浪の方向範囲がB地点でE〜S, C地点でESE〜SEの方向と なっていて, 後者が著しく狭い。

\section{（2）風候および波候の検討}

図-3は3ブイ地点における風速および $10 \mathrm{~m} / \mathrm{s}$ 以上の強風 出現率の累月平均值 $\left(\bar{U}, p_{v}\right)$ と, 波高, 周期および $1 \mathrm{~m}$ 以上の高波出現率の累月平均値 $\left(\bar{H}_{s}, \bar{T}_{s}, p_{u}\right)$, ま た各図の下段は風および波浪の累月測得率 $\left(I_{v}, \Gamma_{H}\right)$ を表す。比較は各地点間で行うことから, 用いる観測資 料の期間をそれぞれの図で短い方に合わせている。まず 風候をみると, いずれの地点においても風速や強風出現 率は冬季に大きく夏季に小さいU字型の月変化を示す。 それらの值はC地点 $<B$ 地点 $<A$ 地点の順に大きくなって おり, 外海部ほど風が強い特性が見出される。

波候をまず湾外のA地点と湾口のB地点についてみると, 波高はA地点で複数の小ピークを伴いながら平均的には 緩やかな逆U字型の月変化を, B地点で緩やかなM字型の 月変化を示し, 相互に若干異なる特性を与えるけれども, いずれの地点でも, 風向の季節特性と方向別対岸距離の 特性を反映して, 風速の月変化と逆位相の関係をとる。
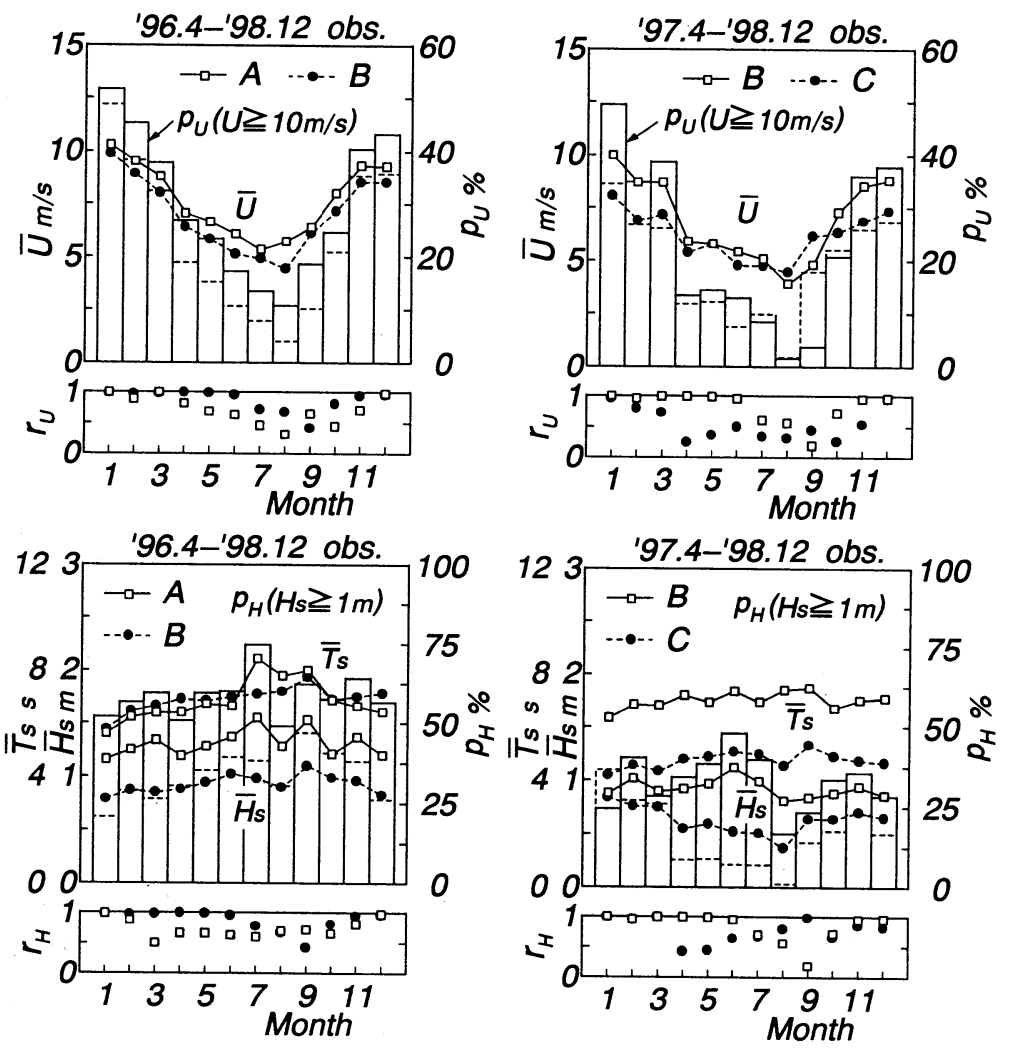

図-3 3ブイ地点における累月風候・波候統計量 


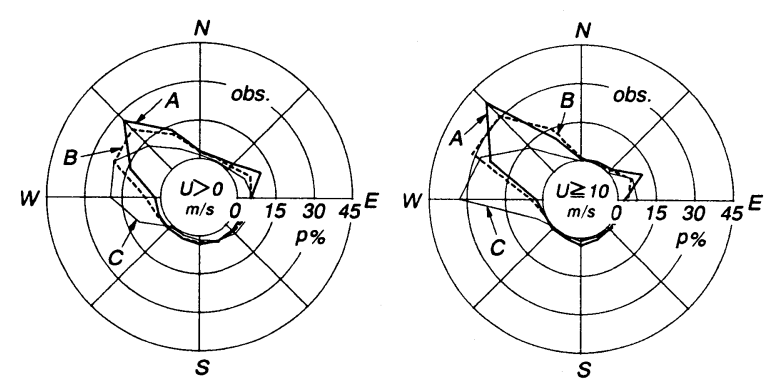

図-4 3 ブイ地点における風向別全風速・強風出現率

高波出現率もA, B両地点で夏季に大きく, 冬季に小さく なっており, 波高の月変化とほぼ符合する。周期は両地 点とも同程度の值をとり，緩やかな逆U字型の月恋化を 与える。要するに, 波高はA地点でより大きく, 周期は 両地点でそれほど差をもたないのが特徴である。

一方, 湾口のB地点と湾内のC地点では, 波高および周 期ともC地点でかなり小さい。月変化の特性をみると, 波高および高波出現率はB地点では5７月でやや大きい 值をとる2〜3ピーク型の月変化を伴うのに対して, C地 点では冬季に大きく夏季に小さいという弱いU字型の月 変化を示す。これはC地点では冬季の湾内風による波浪 が有意な大きさをもつことを示唆する。周期は，その絶 対値は別として, いずれの地点でもごく弱い逆U字型あ るいはM字型の月変化を示し, 夏季にやや大きい傾向に ある。しかし，2つの図におけるB地点の波高の月変化に みられるように, 波候の特性は観測期間や測得率に大い に依存する点に留意する必要がある。

図-4は3ブイ地点における全風速資料および $10 \mathrm{~m} / \mathrm{s}$ 以上 の強風資料の風向別出現率を地点ごとの観測期間につい て示す。外海に面するA, B地点では, 風向の出現率分布 はほぼ符合し, 両資料ともにNWを卓越風向としてNNW〜 WNWの範囲で出現率が高い。このほか, ENE方向にも弱い 出現がみられるが，外海に向いたS〜E方向の風速の出現 頻度が低い。C地点の全風速資料および強風資料におけ る風向別出現率はともにWNあるいはWを卓越風向として NW〜WSWで大きくなっており, 周辺地形の影響によりA, B地点と比べて風の出現方向が若干埼りに傾く。

\section{3. 波浪の長期推算の方法}

\section{（1）海上風資料}

波浪推算における海上風資料として使用する風資料の 1つは, ECMWF (European Centre for Medium-range Weather Forecasts）による，1979〜1998年の20年間に わたる 6 時間間隔の $10 m$ 高度表面風解析値 - 再解析値資料 （ECMWF風資料）である。その空間解像度は1991年9月16 日以前で $1.125^{\circ} ， 1991$ 年 9 月17日以降で $0.5625^{\circ}$ となっ ており, 期間ごとに異なる。

もう1つの風資料は, 1948年1月1日0時〜1998年12月 31 日18時の51年間において6時間間隔で得られているNCEP/

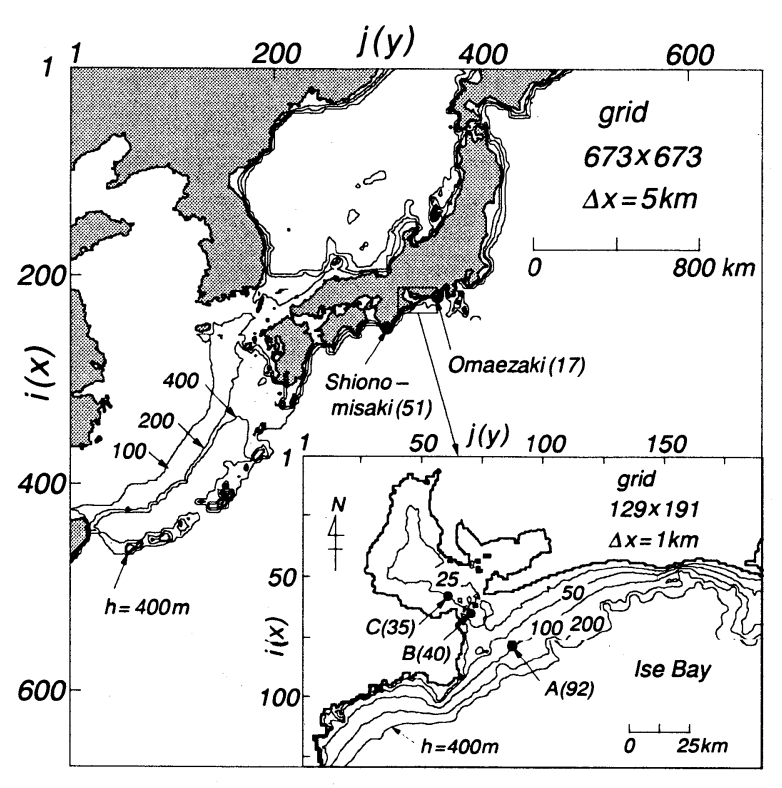

図-5 水深格子網および波浪推算地点の位置

NCAR (National Centers for Environmental Prediction/National Center for Atmospheric Research) Global Reanalysis Archive ds090.0の10m高度表面風再 解析値資料 (NCEP風資料) である。その空間解像度は東 西方向 $1.875^{\circ}$, 南北方向約 $1.9^{\circ}$ となっており, ECMWF 風資料に比べて低い。しかし，NCEP風資料は全期間で同 一の品質管理データ同化システムの適用によって作成さ れているので, 資料の等質性において優れている。した がって, それぞれの特徴に着目して, 空間解像度が相対 的に高いECMWF風資料は波候を調べるための波浪推算に， 等質性が高いNCEP風資料は波高の傾向変動を調べるため の波浪推算に使用する。波浪推算では, 格子間隔 $80 \mathrm{~km} の$ 北西太平洋領域で個別に再構成したECMWF風資料および NCEP風資料を入力条件とする。

ECMWF 風資料やNCEP風資料のうちとくに後者は, 空間 解像度の不足のため, 全般的に風速を過小評価する傾向 にあり, 台風時のように気圧傾度の大きい気象擾乱に対 してその傾向が著しい。そこで, 20 年間のECMWF風速平 均值之NCEP風速平均值の比を6時間間隔のNCEP風速資料 に乗ずることによって，NCEP風速資料を調整をしたのち， 台風モデル風の埋込みによる補正3) を行う。

\section{（2）波浪推算モデルおよび波浪推算条件}

波浪推算には, 山口ほが ${ }^{4)}$ の1点浅海モデルを使用す る。これは, 計算対象地点に到達する各成分波の波向線 上における方向スペクトルの発達・減衰および伝播計算 から，1地点における方向スペクトルの経時変化を計算 する方法であり, 波浪推算モデルとしては第1世代に属 するが, 実用面では高地形解像度格子網上での効率的か つ高(精度の計算) を可能にする。

波浪推算で使用する格子網は, 図-5に示すように, 北 西太平洋領域を格子間隔 $5 \mathrm{~km}$ で $673 \times 673$ （南北 $3360 \mathrm{~km}$, 

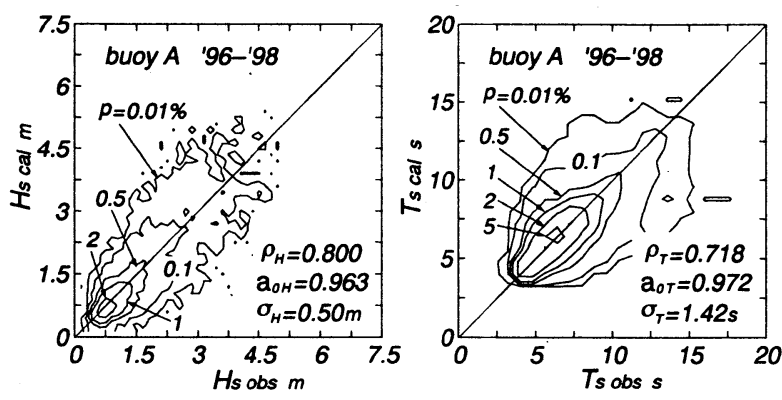

図-6 波高・周期時別值に対する推算資料と観測資料の比較

東西 $3360 \mathrm{~km} ） に$ 分割した大領域水深格子網に，波浪推算 地点周辺領域を格子間隔 $1 \mathrm{~km}$ で分割した伊勢湾周辺小領 域水深格子網を組み込んだ2段階水深格子網である。波 浪推算地点はA，B，Cの 3 ブイ地点であり，NCEP風資料を 入力条件とする波浪推算は観測資料の期間が最も長いB 地点のみで行う。計算に用いる周波数デー夕とその個数 は, 外海からの波浪が到達するA，B地点では，0.04〜 $0.5 \mathrm{~Hz}$ を不等分割した 23 個, 伊勢湾内での発生波浪が有 意な大きさをもつC地点では， $0.04 〜 1 \mathrm{~Hz}$ 間の 27 個とする。 方向データとその個数は 0 ～ $360^{\circ}$ を $10^{\circ}$ 間隔で等分割し た37個である。波浪推算は，時間に関する線形補間を通 じて1時間ごとに格子間隔 $80 \mathrm{~km}$ の格子点上で算出した海 上風を，各成分波に対する波向線上に 2 次元 1 次補間する ことによって, 1時間間隔で行う。

\section{4. 推算資料に基づく波候の解析}

\section{（1）推算精度の検討}

図-6は湾外のA地点について，全観測期間の波高・周 期時別值に対する推算資料（ECMWF風資料を使用）之観 測資料の相関を相対出現率の等值線として示したもので ある。波高について，等值線は完全相関を表す $45^{\circ}$ 直線 のまわりにほぼ対称に図示され，比較的扁平な形をとる ことから, 両者は平均的によく符合するといえる。しか し，高波高部では推算資料の方がやや大きい傾向にある。 これは夏季あるいは秋季の台風来襲時に, 推算波高が観 測波高より大きくなるためである。波高誤差統計量でみ れば, 相関係数 $\rho_{H}$, 原点を通る回帰直線の勾配値 $a_{0 H}$ および2乗平均波高誤差 $\sigma_{H}$ はそれぞれ0.800，0.963およ び0.50mであるから，これらの数值は，推算波高と観測 波高がかなりよく符合するけれども, 波高誤差がやや大 きいことを示す。

周期についても，楕円状等値線の長軸が $45^{\circ}$ 直線とほ ぼ一致し，推算資料と観測資料の平均的な対応は比較的 良い。しかし，等值線形状が波高資料の場合に比べて丸 みを帯び，しかも長周期部で幅広くなっており，両者の 一致度は波高資料の場合と比べてやや低い。因みに，周 期誤差統計量は $\rho_{T}=0.718, a_{0 T}=0.972, \sigma_{T}=1.4 \mathrm{~s}$ であ る。
表-1 推算・観測資料による波候統計量および波候誤差統計量

\begin{tabular}{|c|c|c|c|c|}
\hline $\begin{array}{l}\text { location } \\
\text { (depth) }\end{array}$ & $\begin{array}{c}\mathrm{A} \\
(92 \mathrm{~m})\end{array}$ & $\underset{(40 m)}{B}$ & $\begin{array}{c}C \\
(35 \mathrm{~m})\end{array}$ & $\begin{array}{l}B^{*} \\
(40 \mathrm{~m})\end{array}$ \\
\hline period & $\begin{array}{l}96.4^{-} \\
98.12\end{array}$ & $\begin{array}{l}94.4^{-} \\
98.12\end{array}$ & $\begin{array}{c}97.4^{-} \\
98.12\end{array}$ & $\begin{array}{l}94.4- \\
98.12\end{array}$ \\
\hline$\Gamma_{H}$ & 0.655 & 0.812 & 0.624 & 0.812 \\
\hline$H_{s} 3 \mathrm{~m}$ & $\begin{array}{c}2.19 \\
(2.10) \\
\end{array}$ & $\begin{array}{c}1.64 \\
(1.54) \\
\end{array}$ & $\begin{array}{c}1.03 \\
(1.08)\end{array}$ & $\begin{array}{c}1.59 \\
(1.54) \\
\end{array}$ \\
\hline $\bar{H}_{s} \quad \mathrm{~m}$ & $\begin{array}{c}1.27 \\
(1.31)\end{array}$ & $\begin{array}{c}0.95 \\
(0.95)\end{array}$ & $\begin{array}{c}0.61 \\
(0.63)\end{array}$ & $\begin{array}{c}0.89 \\
(0.95)\end{array}$ \\
\hline $\begin{array}{c}\rho_{H} \\
a_{0 H} \\
\sigma_{H} \mathrm{~m} \\
\end{array}$ & $\begin{array}{c}0.800 \\
0.963 \\
0.50\end{array}$ & $\begin{array}{c}0.770 \\
0.983 \\
0.43\end{array}$ & $\begin{array}{c}0.672 \\
0.881 \\
0.31\end{array}$ & $\begin{array}{c}0.770 \\
0.927 \\
0.42\end{array}$ \\
\hline $\bar{T}_{s} \mathrm{~s}$ & $\begin{array}{c}6.8 \\
(6.8)\end{array}$ & $\begin{array}{c}6.6 \\
(6.8)\end{array}$ & $\begin{array}{c}4.5 \\
(4.8)\end{array}$ & $\begin{array}{c}6.7 \\
(6.8)\end{array}$ \\
\hline $\begin{array}{l}\rho_{T} \\
a_{0 T} \\
\sigma_{T} \quad \mathrm{~s}\end{array}$ & $\begin{array}{c}0.718 \\
0.972 \\
1.4\end{array}$ & $\begin{array}{c}0.656 \\
0.957 \\
1.5\end{array}$ & $\begin{array}{c}0.586 \\
0.934 \\
1.3\end{array}$ & $\begin{array}{c}0.631 \\
0.970 \\
1.6\end{array}$ \\
\hline
\end{tabular}

( ) : obs., * : NCEP wind data

表-1はECMWF風資料を入力条件とするA，B，C地点の推 算資料について, 波候統計量である $1 / 3$ 最大平均波高 （波高資料 $H_{s}$ の上位 $1 / 3$ の平均値） $H_{s} 3$ ，平均波高 $\bar{H}_{s}$, 平均周期 $\dot{\bar{T}} s$ と, 波高誤差統計量 $\left(\rho_{H}, a_{0 H}, \sigma_{H}\right)$ お よび周期誤差統計量 $\left(\rho_{T}, a_{0 T}, \sigma_{T}\right)$ をブイの設置水 深, 観測期間および測得率 $I_{\text {H }}$ とともに一括して示した ものである。B地点についてはNCEP風資料を入力条件と する推算資料についての結果も与えている。これから， 各波候統計量に関して，それぞれの地点で推算資料 （ECMWF風資料を使用）は観測資料とよく符合すること や，波候誤差統計量はA，B地点での推算資料と観測資料 の比較的高い一致とC地点での相対的に低い相関を表す こと, さらに, NCEP風資料を入力条件とするB地点の推 算資料もECMWF風資料の場合と同程度の精度を有するこ となどが示唆される。C地点における推算精度の低下は, 空間解像度 $0.5625^{\circ}$ のECMWF風資料が伊勢湾内の風特性 に及ぼす周辺地形の影響を必ずしも適切に評価しないこ とによる。

図-7は3ブイ地点における累月波候統計量 $\left(H_{s} 3, \bar{H}_{s}\right.$, $\left.\bar{T}_{s}\right)$ の比較を示す。推算資料はECMWF風資料を入力条件 として得ている。資料期間は各地点の観測年数に応じて 2〜 5年と異なる。波浪推算は，A，B地点の観測資料に見 出される波高統計量の逆U字型あるいは非対称W字型の月 変化やC地点のごく緩やかなU字型の月変化, および地点 間の波候統計量の相違, とくにA地点における波高がB地 点より大きいのに対して, 周期はあまり差を伴わない特 徵や，C地点ではA，B地点に比べて波高・周期ともかな り小さい值をとる特徵を比抆的良く再現する。

また，推算資料および観測資料に基づく累月波候統計 


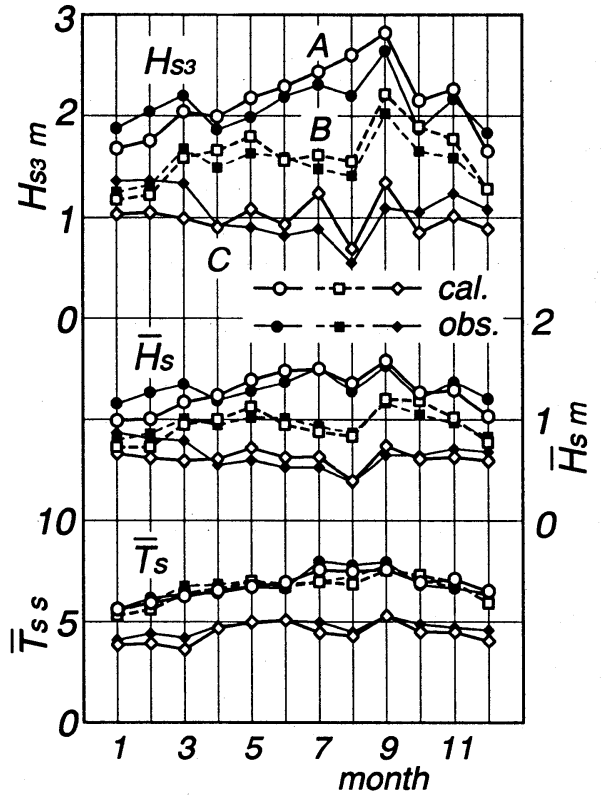

図-7 3ブイ地点における累月波候統計量の比較
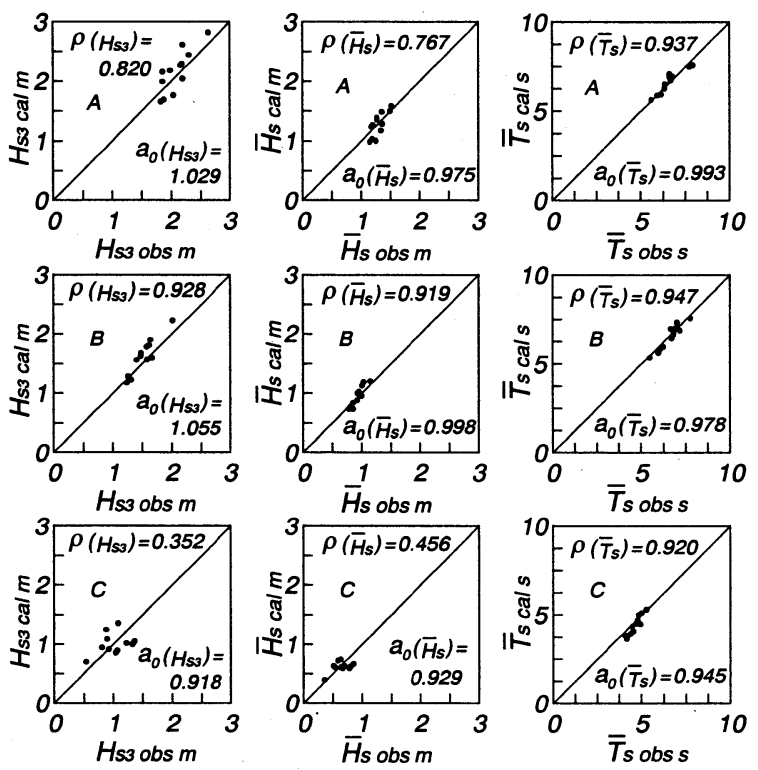

図-8 3ブイ地点における累月波候統計量の相関

量 $\left(H_{s} 3, \bar{H}_{s}, \bar{T}_{s}\right)$ 間の対応をより明確にするために, 両者の相関を図示したのが図-8であり，図中にはこの場 合の相関係数および原点を通る回帰直線の勾配值，たと えば $1 / 3$ 最大平均波高 $H_{s} 3$ について $\rho\left(H_{s} 3\right), a_{0}\left(H_{s} 3\right)$ も 与えている。これらの図から, いずれの地点でも推算資 料と観測資料に基づく結果は平均的に符合し，とくにB 地点における両資料の対応が最も良いこしや，高波高部 を代表する $1 / 3$ 最大平均波高 $H_{s} 3$ に関して推算資料が観 測資料よりやや大きめの値を与えること，さらに湾内の C地点では波高統計量の再現精度がA，B地点に比べて低 いことなどが見出される。

つぎに, 年別波候統計量 $\left(H_{s} 3, \bar{H}_{s}, \bar{T}_{s}\right)$ について それぞれECMWF風資料およびNCEP風資料を入力条件とす

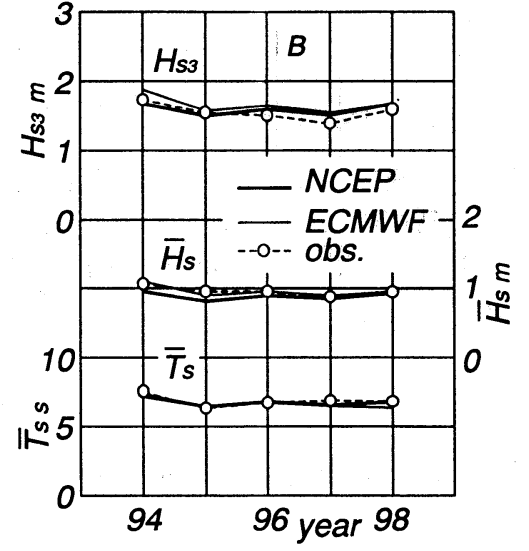

図-9 B地点における年別波候統計量の比較

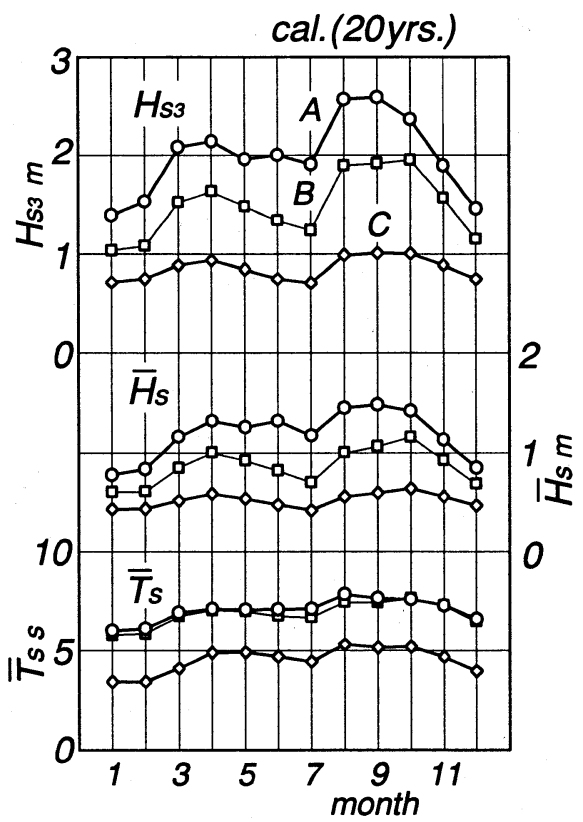

図-10 3ブイ地点における累月波候統計量

る推算資料と観測資料に基づく結果を比較したのが図-9 である。両推算資料は類似した年変化を示し, 観測資料 とも比較的良く符合する。したがって，51年間のNCEP風 資料を入力条件とする波浪の長期推算資料を用いて波高 の傾向変動を検討することが可能と判断されよう。

\section{（2）波候および波高の傾向変動の検討}

図-10は20年間のECMWF風資料を入力条件とする推算資 料より得た各地点の累月波候統計量 $\left(H_{s} 3, \bar{H}_{s}, \bar{T}_{s}\right)$ を表す。各地点の波候統計量の月変化は, 図-7に与えた 観測期間に相当する結果と類似するけれでも，B地点と 同様にA地点のみならずC地点においても, わが国太平洋 岸で出現する非対称M字型の月変化の特徴をとくに波高 について明確に示す点で, 資料期間の影響が現れる。ま た, 波高はA，B，C地点の順に小さくなるのに対して, 周期はA, B地点でほとんど同程度の值をとり, C地点で は小さい特徴も見出される。図-11は20年間の全波高資 

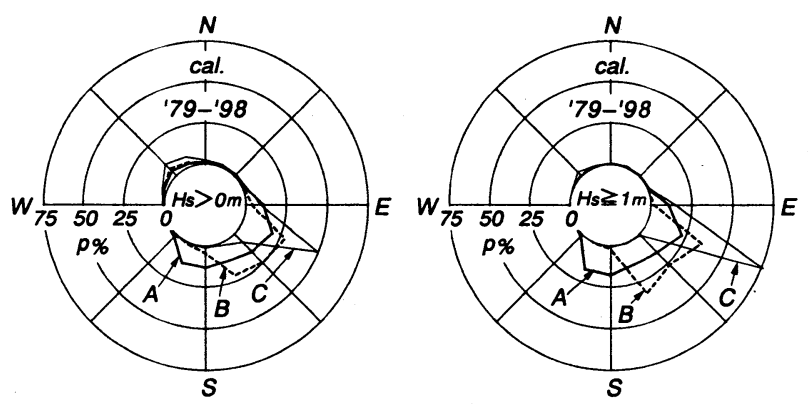

図-11 階級別波高の波向別出現率

料と1m以上の波高資料による波向別出現率を表す。湾外 のA地点における卓越波向はSSW〜Eであるが，波高が大 きいほどあるいは湾口から湾内に至るにつれて卓越波向 の範囲が狭くなり，とくに湾内のC地点では高波の卓越 波向はほほEEに限定される。

ついで，図-12はNCEP風資料を入力条件とする推算資 料から得た B地点における 51 年間の年別波高統計量

$\left(H_{s} 3, \bar{H}_{s}\right)$ を示す。年別波高統計量は, 多少の変動を 繰り返すものの, NCEP風資料の質的な問題 ${ }^{3)}$ に起因する と考えられる最初の 10 年程度を除いて, 一方向的な変化 傾向をもたないようにみえる。年別波高統計量の傾向変 動を定量的に表すために，年別波高統計量資料に1次式 をあてはめたのち, $t$ 分布の理論に基づいて勾配值が0 いう仮説が成立するか否かの片側検定を有意水準 $5 \%$ で 行い, 統計的に有意な増加あるいは減少傾向が検出され る場合それぞれ傾向変動判別指標 $L=1$ あるいは- 1 , 検出 されない場合 $L=0$ として，その結果を表す。また，もう1 つの指標として, 鈴木6) ${ }^{6}$ によるトレンド示数 $I_{T}$ を用いる。 有意水準を $5 \%$ とすれば， $I_{T}>1.65$ で増加傾向， $I_{T}<-$ 1.65 で減少傾向, $\left|I_{T}\right| \leqq 1.65$ で増加・減少傾向なし, と 判別する。まず，最初の 10 年間の資料に上述の問題を伴 う51年間資料では，各年別波高統計量は統計的に有意な 増加傾向を与える。一方, NCEP風資料が等質とみなされ る41年間（1958～1998年）の各年別波高統計量資料の勾 配值 $a$, 勾配值に対する傾向変動判別指標しおよびトレン ド示数 $I_{T}$ は, $1 / 3$ 最大平均波高 $H_{s} 3$ に対して $(0.094 \mathrm{~cm} / \mathrm{year}, 0,0.92)$ ，平均波高 $\bar{H}_{s}$ に対して $(0.044 \mathrm{~cm} / \mathrm{year}, 0,0.108)$ と求められる。勾配值はい ずれも正の值をとるから，各年別波高統計量は増加傾向 をもつけれども, 傾向変動判別指標は $L=0$, トレンド示 数は $\left|I_{T}\right|<1.65$ であるから, 統計的有意性を考慮すれ ば，各年別波高統計量は増加・減少傾向をもたないと判 定される。この結果は，わが国沿岸の大部分で過去 41 年 の間に年別波高統計量の統計的に有意な傾向変動は検出 されないという畑田ほが)の結果と整合する。

\section{5. 結 語}

本研究で得られた結果の要点はつぎのようである。 (1)観測資料の解析によれば, 伊勢湾口内外の 3 ブイ地点

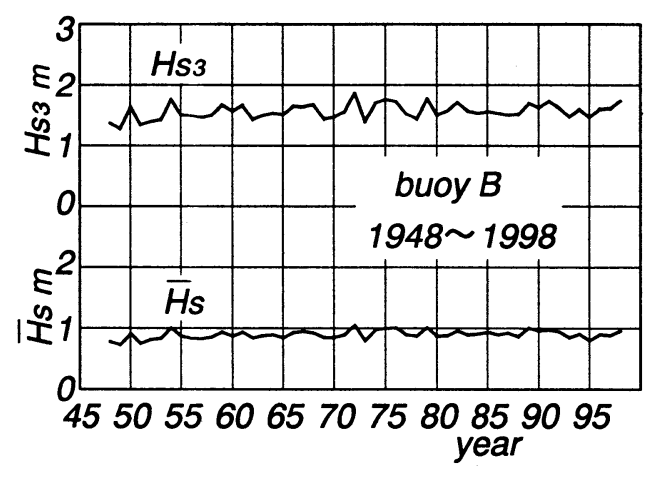

図-12 B地点における年別波高統計量の年変化

における風候はU字型の月変化を, 波候は湾外のA地点と 湾口のB地点でそれぞれ緩やかな逆U字型あるいは非対称 $\mathrm{M}$ 字型の月変化を示し，相互に逆位相の関係を与える。 また, 風・波浪の規模は湾外から湾口, 湾内に向けて減 少するが，周期はA，B地点で同程度の值をとる。 (2)波浪の長期推算システムは, A, B地点の周期があまり 変化しない特徴を含めて観測資料の解析から得た $\mathrm{A}, \mathrm{B}$, C地点の波候の特性をよく再現する。ただし, 風資料の 空間解像度の制約のために, C地点ではその再現性がA, B地点に比べて低下する。

(3)波浪の長期推算資料の解析によれば，3ブイ地点にお ける波候は，わが国太平洋岸の波候の特徴である非対称 M字型の月変化を示す。また, 過去41年の間に統計的に 有意な波高の傾向変動は検出されない。

謝辞 : 風・波浪観測資料を提供戴いた(旧)建設省中部地 方建設局東海幹線道路調査事務所に謝意を表する。

\section{参考文献}

1）渥美 勉 : 伊勢湾口道路の調查概要，土木學会誌，V0l.84, No. 10, pp. 69-72, 1999.

2）畑田佳男, 山口正隆, 大福 学, 李 敏杰, 野中浩 : 波 浪の長期推算に基づく波候と波高極值の推定システム, 自 然災害科学 J. JSNDS, 19-2, pp. 205-225, 2000.

3）山口正隆, 畑田佳男, 野中浩一, 大福 学: 台風モデル風 の埋込みによる51年波浪推算システムの改良, 海岸工学論 文集, 第49巻, pp. 206-210, 2002.

1）山口正隆, 畑田佳男, 宇都宮好博: 一地点を対象とした浅 海波浪推算モデルとその適用性，土木学会論文集，No. 381 /II-7, pp.151-160, 1987.

5）畑田佳男, 山口正隆, 大福 学: 1点浅海モデルおよびAM による長期波浪推算結果の相互比較, 海岸工学論文集, 第 46巻, pp. 271-275, 1999.

6) 鈴木栄一: 気象統計学 (第5版)，地人書館， 1975.

7) 畑田佳男, 山口正隆, 大福 学, 李 敏杰, 野中浩一: わ が国沿岸での長期波浪推算資料に基づく波高の傾向変動の 解析, 海岸工学論文集, 第49巻, pp. 1346-1350, 2002. 